\title{
Correction to: India's China strategy under Modi: continuity in the management of an asymmetric rivalry
}

\author{
Manjeet S. Pardesi ${ }^{1}$
}

(C) Springer Nature Limited 2021

\section{Correction to: International Politics \\ https://doi.org/10.1057/s41311-021-00287-3}

The original article is published with incorrect article title. The correct article title is "India's China strategy under Modi: continuity in the management of an asymmetric rivalry".

Publisher's Note Springer Nature remains neutral with regard to jurisdictional claims in published maps and institutional affiliations.

The original article can be found online at https://doi.org/10.1057/s41311-021-00287-3.

\section{Manjeet S. Pardesi}

manjeet.pardesi@vuw.ac.nz

1 International Relations at Victoria University of Wellington, Wellington, New Zealand 